\title{
Media, justice in Tonga
}

It is my belief that such a move to form a new media association of the nature of Pacific Islands Media Association (PIMA) is spear-headed by a group of people who have a common interest and common understanding, and a vision for the future role of media in the region.

\section{By S ‘AKILISI POHIVA}

AT A time when media exercise more influence than at any other time in human history, when violence against journalists is increasing and when governments - many of them in Eastern Europe, in Asia and in the Pacific — resist pressure to recognise universal principles of freedom in society, the role of media has become an issue that defines the quality of democracy and freedom.

It is my belief that such a move to form a new media association of the nature of Pacific Islands Media Association (PIMA) is spear-headed by a group of people who have a common interest and common understanding, and a vision for the future role of media in the region.

If I am right in my speculation then this is a chance for me to share with you my observations and the experience I have gone through as a journalist and as a political activist.

Initially, I was engaged in the teaching profession. While in teaching, I launched a private radio programme on Tonga's state-owned radio station in 1981 which raised, for the first time, major social and economic issues for public discussion and dialogue. That radio programme was shut down by government in January 1985 followed by my dismissal from government service in February.

That incident was no doubt a violation of freedom of speech protected by Clause 7 of our Constitution. So, with the help of a lawyer from here (New 
Zealand), a court proceeding was filed against the Prime Minister and Tongan Government for wrongful dismissal. Part of Justice Martin's judgement in the said case reads as follows:

The reality of the situation is that Mr Pohiva was dismissed because he was the thorn in the government. He was held responsible for a series of radio programmes which contain materials critical of government.

Cabinet was not satisfied with merely banning the programme. They were determined to punish and if possible to silence the person whom they believe to be responsible for it. It was a blatant move to suppress criticism. As Mr Harrison put it, speech which is punished is not free. This was an interference with Mr Pohiva's right of free speech and the defendant is liable to tort.

The outcome of the said case marks the beginning of a new era in the development of the media in Tonga. My newspaper Kele' $a$ came out in 1986 to carry out the mission undertaken by the radio programme shut down by Government. In 1988, Kalafi Moala joined in by launching Taimi 'o Tonga. Since then, the public continued to have access to alternative views and opinions on a weekly basis, which had never been voiced, discussed and debated publicly before.

All along from 1988, the court of justice became a battleground for journalists and activists, on one side, and the guardians of the status quo and the conformists, on the other side. The last time I was in court, as a defendant, was in April 2001 with the Government Auditor-General as the plaintiff on a civil defamation case. Just a week before the PIMA conference, a police magistrate delivered his judgement on a preliminary hearing on a criminal defamation case between the Minister of Justice and Attorney-General as the prosecutor and the editor of the state-owned Tonga Chronicle, Oceania Broadcasting Networks and others as the defendants.

Among the eighteen criminal and civil defamation cases filed against me during the last fifteen years, there was one with the Attorney-General, on behalf of the King, as the prosecutor, and one with the Crown Prince, as plaintiff, in a civil defamation action. All these battles in court reflect a struggle between the conservative guardians of the traditional aristocracies and those representing the advent of a new social order. What is significant in the case of Tonga is not the one who wins or loses in the battles in court. It is rather the ability, the moral 


\section{INDEX}

courage and commitment of those involved in the struggle and the effective and proper utilisation of media resources and outlets for the purpose being served, is significant.

Media freedom in most of the small states is treated with suspicion and, as confrontational to the normal function and security of the establishment. A prime example in Tonga is the Tonga Human Rights and Democracy Movement's request for a weekly programme to be broadcast on the Government radio station. One of the conditions included in our request is that the written scripts of every programme would be made available to the station for screening before broadcast. Our request was turned down. An appeal has been lodged with the Prime Minister from our office against the decision being made. Now, nine months has gone by and still no answer has been received.

In the case with the Tonga Development Bank, the issues raised by Kele' $a$ articles went significantly further than mere competent administration and favouritism by the plaintiff (TDB) to certain customers. The allegation made by Kele' $a$ was that the government agency had jeopardised public funds, causing consequential financial losses to small growers who were dependant on it and allowing substantial loans over which it had control to continue in default. The further allegation was that of favouritism or, perhaps more precisely, so far as the director borrowers were concerned, "conflict of interest'. The grounds for the alleged favouritism, that is, the connection of one borrower with the royal family and the status as directors of the plaintiff of other borrowers were issues of crucial public concern. The fact that the articles were based on true information and made valid and important should have been taken into account by his honour in assessing the public interest defence. There is no indication that he did so in assessment of the case with TDB. However, in his judgement, J Dalgety said:

The defendant in this case immediately on receiving from the plaintiff dissent employee the information he subsequently published in Kele' $a$, was subject to an obligation of secrecy and confidence. He ought to be restrained from publishing the like in the future.

Further, Justice Dalgety granted a disclosure order in his judgement as a consequential relief.

In the submission of my lawyer, Dr Rodney Harrison from Auckland, he says that when a disclosure order is sought against a journalist in the case of 98 PACIFIC JOURNALISM REVIEW 82002 
Tonga, it needs to occur in a broader Tongan constitutional context. Firstly, there is no official information regime in force in Tonga such as exists in the United States and in other Commonwealth jurisdiction. Secondly, the present overall constitutional arrangements as well known, ensure that His Majesty the King and the nobles have a constitutional majority and thus control of Parliament and of the executive. It is not constitutionally possible for an opposition party, as such, to gain access to the executive flow of information or the details of internal workings of public corporations such as the Tonga Development Bank and statutory boards without the express cooperation of the executive. Furthermore, there is no formal and regular basis to provide scrutiny of issues of public expenditure. Thirdly, it must appropriately be the subject of judicial knowledge that there is currently in Tonga a significant call for greater participation by commoners in the government of the country overall. In that context, issues raised in the various articles in the Kele' $a$ which, caused Government and its supporters to sue the editor take on a special significance.

However, in the end the Court of Appeal dismissed the appeal.

One of the particulars of an offence levelled against me in another civil action in 1995 was as follows:

Samuela 'Akilisi Pohiva on, or about August 1994, did defame His Majesty the King by telling Micheal J Ybarra which was later published in the Wall Street Journal of 23 August 1994, any one or more of the following defamatory statements:

The King is a dictator.

The King and his nobles are guilty of financial legerdemain.

The King has ignored requests to account for the funds from the sale of Tonga passports.

In a response to a letter of Minister of Justice and Attorney-General to me requesting my apology on the ground that my statement published in the Wall Street Journal defamed His Majesty, I said:

Hon. Minister, I believe there is no ground for me to make an apology as requested.... as the statements I made were done independently based on factual occurrences... (Mr Minister), the only way for the King to evade criticisms is a total isolation from the law making and the executive position to become an Honorary King like the King of Britain and other dynasties in Europe. . [I continued] the only leader in the universe that 


\section{INDEX}

cannot be subjected to criticisms is Jehovah, the King of Kings and Lord of Lords. His reign is righteous and flawless... His leaderships is free of prejudice and unchallenged.

(That part of my response to the minister's letter was quoted in Justice Finnigan's decision in the King vs Pohiva in the Supreme Court of Tonga, Page 17)

I made these remarks in my response to the minister's letter in a hope that would clear my position to the minister once and for all. Unfortunately, the minister did not want to take the bitter medicine. So, he decided to take me to court for defaming His Majesty.

Justice Finnigan goes further and says:

It is not shown to my satisfaction that the accused said that. (the King is a dictator). But, if he did then, in their context, those words can only mean, the King is an authoritarian ruler who ignores my repeated requests for accountability by himself and His Ministers... if he said that, it appears to me to be the truth. Taking into account of the evidence by the accused during the trial it appears to me not surprising that his attempts to obtain accountability in a system which does not provide for it are ignored. (p 26)

... Finally, I must refer briefly to the submission made that, in writing what he did in Kele' $a$, assuming it to be defamatory, the accused was in breach of his oath as a member of the Assembly, taken pursuant to section 83 of the constitution. In my view the accused, in writing his views in a newspaper outside the term and context of any sitting Legislative Assembly, was not necessarily acting within the scope of the activities contemplated by his oath to serve as a member of the Legislative Assembly. There is no substance in this submission.

For the reasons stated above in respect of Count 1. For the reasons stated above in respect of Count 2 the accused is acquitted of Count 2.

In September 1996, the Legislative Assembly ordered the imprisonment of Samuela 'Akilisi Pohiva; Kalafi Moala, editor of Taimi 'o Tonga; and Filokalafi 'Akau'ola, deputy editor of the same newspaper; for thirty days commencing at $5 \mathrm{pm}$ on the afternoon of 19 September 1996 by virtue of the power vested in the Legislative Assembly by clause 70 of the Constitution and the judgement of the House on this day regarding their imprisonment. They were not to be released 
The evidence indicated that before the order to imprison the defendants was

made, a summons was served on them.

The defendants were persuaded to apologise and the case would be dropped. But the defendants refused.

until after the expiration of thirty days or otherwise ordered by Parliament for a shorter time.

The evidence indicated that before the order to imprison the respondents was made, a summons was served upon the defendants containing the following allegations.

\begin{abstract}
There is a complaint to the Legislative Assembly of Tonga regarding the newspaper Taimi 'o Tonga, '.... It publishes an article on impeachment by the Legislative Assembly...
\end{abstract}

The article began by informing its readers that an impeachment of the Minister of Justice had been submitted by the Peoples' Representative to the Parliament of Tonga. Prominent among the complaints on which it was proposed to base the impeachment was a complaint that the Minister of Justice had attended the Olympic Games in Atlanta, Georgia, in the United States, after Chairman of the House, not the Legislative itself, had declined an application for leave.

During the hearing the defendants were persuaded to apologise and the case would be dropped. But the defendants refused.

Part of the Court of Appeal's judgement on the said case reads as follows:

To discuss legislation or other resolution proposed, or to be proposed, to the Legislative Assembly, or passed or to be passed by it, is of the very essence of constitutional polity, which Tonga is, as clause 31 of the Constitution explicitly states. Indeed, clause 7 makes freedom of the press subject only to the law of slander and the protection of the Crown. What Milton wrote, translating Euripides' ("Dore" of The Complete Poems of John Milton, vol. 11, p 665), is embraced by our constitution: This is true liberty, when freedom men 


\section{INDEX}

Having to advise the public may speak free; ...

What can be juster in a state than this?

... Accordingly, this Court holds that the Chief Justice was right in understanding $\mathrm{cl} .70$ as entitling the respondents to natural justice. But the better view of the evidence is not that they were denied natural justice, but they were convicted of an offence that did not exist.

In Tonga, the concept of media freedom and the right of people to be well and truly informed is directly opposed to the values and hidden agenda of those who rule and control the resources. Much of the activities created in the name of development is concerned with improving the efficiency of, and thus maintaining the status quo, rather with the developing of mature people. Such a situation is, again a challenge to the role of media in Tonga.

It is significant to mention that while all these developments are affecting media freedom in the Pacific, it is very encouraging to learn that there are people and media organisations in other parts of the world who are very much concerned with freedom of press in the region.

After Justice Dalgety made a disclosure order in his ruling in the case with Tonga Development Bank, the associate director, Joel Solomon, on behalf of the Committee to Protect Journalists, wrote a letter to Justice Dalgety. In the letter dated 14 December 1995, he says:

As a non-partisan organisation that defends press freedom world-wide, the committee is concerned that steps taken against the newspaper and its editor are in contravention of internationally recognised standards of press freedom, such as Article 19 of the Universal Declaration of Human Rights of the United Nations which guarantees the right to seek, receive and impart information and ideas through any media and regardless of frontiers. Though we understand that the information at issue may have been sensitive, it appears that Kele' $a$ has done nothing more than report on a matter of public interest, as any news media should be free to do. ... We respectfully urge that the case against Kele' $a$ be re-examined with the broadest possible consideration for the importance of press freedom in Tonga. We further request impediment and that Mr Pohiva not be compelled to reveal the paper's source.

In the defamation case between Pohiva and the Crown Prince of Tonga, the Crown Prince's lawyer in Auckland wrote to the editor and suggested that the 


\section{BICULTURALISM}

Crown Prince would consider possible settlement if the editor makes a public apology. The editor refused, not because of a point of law, but because of a pursuit of the fundamental principle of equity and justice. All other cases of the said defendant with the senior government officials, including the case with the King, require settlement outside court upon publication of a public retraction by the defendant. But, so far, no apology has been given.

Three weeks before the PIMA conference in Tonga, stories leaked out to the peoples' representatives disclosing the loss of the Trust Funds investment of about US\$26 million in the stock market in America. Evidence of the lost investment came to the hands of the peoples' representatives. So, in Parliament, enormous pressure was brought against the King's Privy Council demanding the resignation of the members of the Trust Fund's Committee for maladministration and incompetency. The message of the peoples' representatives came out to the people loud and clear. So, on Friday a week before the conference, the Deputy Prime Minister and Minister of Justice and AttorneyGeneral, David Tupou, a member of the Trust Fund's Committee, was forced to tender his resignation before $4 \mathrm{pm}$. And on Monday, the former Minister of Finance and former member of the Trust Fund's Committee, now Minister of Education, was also forced to tender his resignation. The removal order came from Princess Pilolevu, who was the Princess Regent during the absence of the King from the country.

If you ask me what are the factors that caused the removal order, I would say, one is the power of the media. Two, is the active participation of journalists in exposing the said crisis. Parliament first took it up. Since then it has become headlines on TV 7 and on the local newspapers. Media in New Zealand and Australia also picked it up and relayed it to the rest of the world.

Way back in 1996 it was the Commonwea1th Press Union branch of New Zealand and Australia that sponsored a civil rights lawyer, Barry Wilson from New Zealand, to come to Tonga to represent Kalafi Moala, editor of Taimi 'o Tonga, Filokalafi 'Akau'ola, deputy editor, and me in a habeas corpus legal proceedings which resulted in our release from jail.

There have been a lot of similar incidents in most of the small states in the Pacific that have not been, or could not be brought to the attention of the international human rights communities and international media organisations because of the absence of a reliable and independent regional media association. The Pacific Island News Association (PINA) is there to cater for the need of the small states, but it does not have the autonomy to operate independently as most 


\section{INDEX}

of the members of the executive are closely tied up to their respective governments. This conference is a chance to look at this area of major concern.

In our struggle in Tonga I always look at history as a continuing struggle between the advocates of development and the guardians of the status quo. The revolutionary advocates are, and have been, engaged in Freire's Cultural Action for Freedom, which is utopian in nature. I quote:

Revolutionary utopia tends to be dynamic than static, tends to life rather than death; to the future as a challenge to man's creativity rather than a repetition of present; to love as liberation of subjects rather than pathological possessiveness... to men who organise themselves reflectively for action rather than men who are organised for passivity, to reflective challenges rather than domesticating slogans; and to values that are lived rather than myths which are imposed (Freire, 1977:72).

One of the areas this conference may have time to look at is the lack of media outlets and resources through which crisis and serious issues of major concern in the small states could be communicated to the rest of the world.

Once again, I hope this conference is a chance for all the participants, to share among ourselves views and thoughts on what this association could do to facilitate the real needs of the people in the region at these most difficult times.

$\square S$ 'Akilisi Pohiva is leader of the commoner pro-democracy Members of the Tongan Parliament and is publisher of the newsletter Kel'ea. This was the opening speech of the inaugural Pacific Islands Media Association (PIMA) conference, "Navigating the Future", at Auckland University of Technology, New Zealand, 5-6 October 2001.

www.pima.org.nz/pohiva_speech.doc 